\title{
Novedades en el ecosistema de revistas colombianas del área de ingeniería y tecnología
}

En esta editorial se pone en contexto la situación actual de las revistas colombianas del área de ingeniería y tecnología desde la aplicación del nuevo modelo de clasificación de revistas científicas Publindex [1], y se da a conocer el ascenso de la Revista UIS Ingenierías de categoría C a categoría B en Publindex. Además, se relacionan algunas actividades que se realizaron con el propósito de conseguir el ascenso.

En Colombia, las revistas nacionales son clasificadas por Colciencias, quien a su vez cuenta con el Servicio Nacional de Indexación de Publicaciones Especializadas Seriadas de Ciencia, Tecnología e Innovación (Publindex), encargado de evaluar la calidad de las publicaciones editadas en el país.

La Revista UIS Ingenierías (RUI) es una publicación arbitrada por pares, de circulación trimestral, editada por la Facultad de Ingenierías Fisicomecánicas de la Universidad Industrial de Santander. Desde el año 2002, esta revista ha sido el espacio de difusión de las investigaciones desarrolladas por académicos y profesionales de la ingeniería, el diseño industrial y las ciencias aplicadas, por lo cual ha facilitado el intercambio de conocimiento científico entre particulares y entidades nacionales e internacionales animadas por propósitos similares [2].

Durante los años 2016 y 2017, en el país se implementó un nuevo modelo de clasificación de revistas científicas [1], mediante el cual Colciencias adoptó herramientas de evaluación acordes con las tendencias internacionales, como son los indicadores de impacto y la incorporación en Sistemas de Indexación y Resumen. Todo esto con el propósito de ajustar los estándares de calidad científica y editoriales en Colombia e incrementar el impacto de las publicaciones científicas nacionales. Acorde con los cambios, y en una posición no favorable para la convocatoria por venir, RUI inició un proceso de adaptación para cumplir los criterios de Publindex.

El modelo de clasificación de revistas científicas agrupa las publicaciones, a partir de la categorización de la Organización para la Cooperación y el Desarrollo Económicos (OCDE), en 6 grandes áreas del conocimiento. Estas áreas son ciencias agrícolas, ciencias médicas y de la salud, ingeniería y tecnología, ciencias naturales, ciencias sociales y humanidades. La Revista UIS Ingenierías se encuentra ubicada en el área de ingeniería y tecnología.

En la figura 1 se relaciona el proceso de evaluación y los criterios planteados en el modelo de clasificación de revistas científicas. En esta se observa que la clasificación está determinada por el indicador de impacto, en donde las revistas indexadas en las bases bibliográficas, Web of Science (WoS) y Scopus, reciben la categoría que les otorgan los informes sobre citas en revistas científicas, Journal Citation Reports (JCR) y Scimago Journal \& Country Rank (SJR), respectivamente. Para la revistas no indexadas en estas bases, el indicador corresponde al índice h5 [3], calculado mediante el software libre Publish or Perish (PoP) [4].

Figura 1. Proceso de evaluación y criterios planteados en el modelo de clasificación de revistas científicas.

FASE I

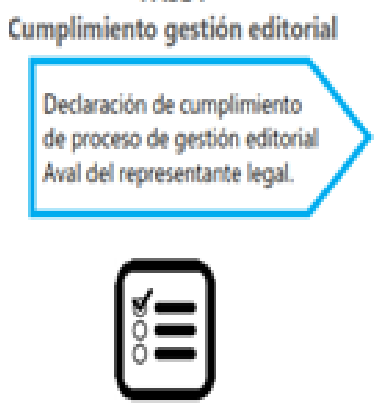

FASE II
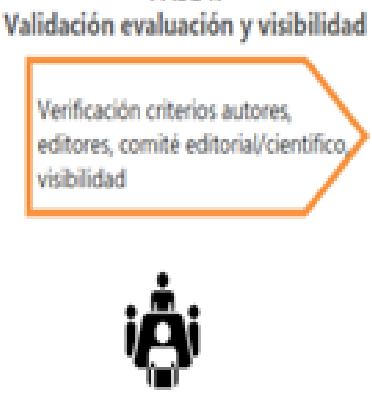

FASE III
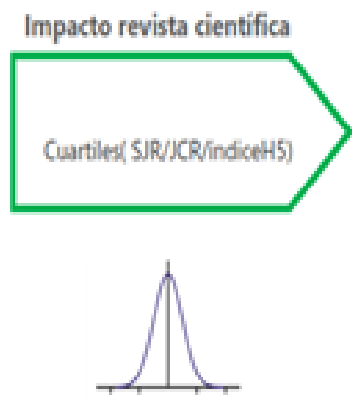

\begin{tabular}{|r|c|c|}
\hline Categoría & $\begin{array}{c}\text { JCR } \\
\text { o } \\
\text { SJR }\end{array}$ & $\begin{array}{c}\text { h5 } \\
\text { (Calculado } \\
\text { con PoP, } \\
\text { mínimo 2) }\end{array}$ \\
\hline A1 & Q1 & n/a \\
\hline A2 & Q2 & n/a \\
\hline B & Q3 & Q1 \\
\hline C & Q4 & Q2 \\
\hline \multicolumn{2}{|r|}{ Sin categoría } & Q3 \\
\hline \multicolumn{2}{|r|}{ Sin categoría } & Q4 \\
\hline
\end{tabular}

Fuente: elaboración propia a partir de [1].

ISSN impreso: 1657 - 4583. ISSN en línea: 2145 - 8456, CC BY-ND 4.0 (c) (1)

I. Sáenz-Suárez, A. Pertuz-Comas, "Novedades en el ecosistema de revistas colombianas del área de ingeniería y tecnología," Rev. UIS Ing., vol. 18, no. 4, pp. 7-14, 2019. doi: 10.18273/revuin.v18n4-2019018 
En el año 2016 se dio apertura a la Convocatoria N. ${ }^{\circ} 768$ para la Indexación de Revistas Científicas Colombianas Especializadas Publindex. Esta fue la primera bajo el nuevo modelo y la categoría obtenida tuvo vigencia por dos años, 2018 y 2019. Según el Informe de la Convocatoria N. 768 [5], publicado en septiembre de 2017, por la Dirección de Fomento a la Investigación, se registraron en total 627 revistas, de la cuales 244 fueron categorizadas.

En el área de ingeniería y tecnología se presentaron 76 revistas, y solo 30 fueron clasificadas; el $61 \%$ de las revistas del área se quedó sin categoría. De las 30 revistas categorizadas, ninguna se ubicó en la categoría A1, solo una revista fue clasificada en la categoría A2, 10 en la categoría B y 19 en la categoría C (ver figura 2). La Revista UIS Ingenierías (RUI) en esa oportunidad logró clasificarse en la categoría C.

Figura 2. Distribución del ecosistema de revistas del área de ingeniería y tecnología, Convocatoria N. ${ }^{\circ} 768$ de 2016.

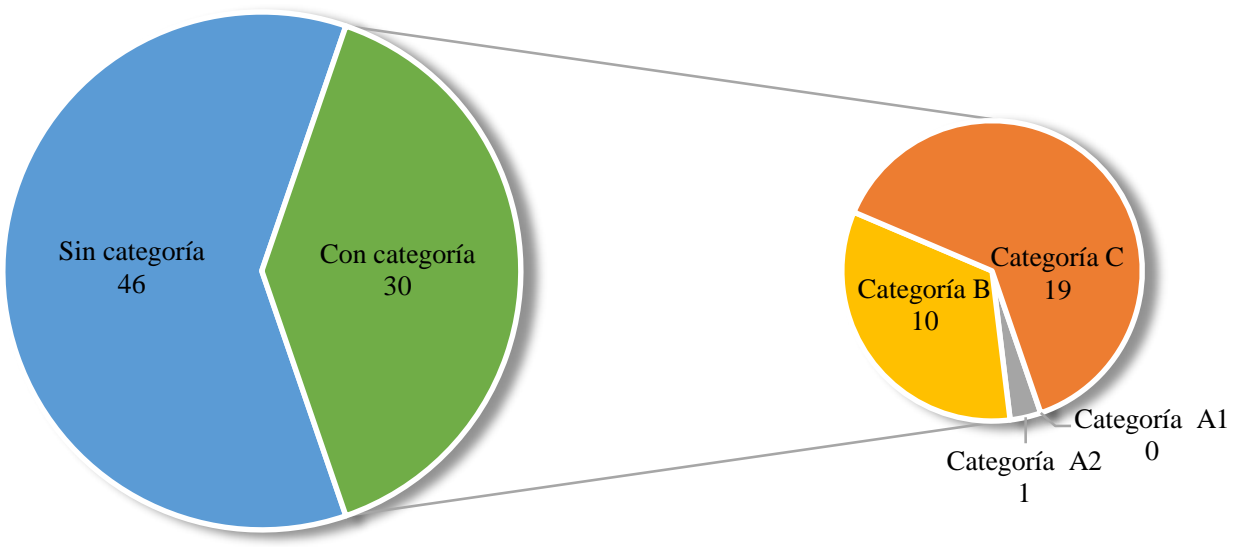

Fuente: elaboración propia.

De las 76 revistas del área de ingeniería y tecnología, 5 se encontraban indexadas en Web of Science (WoS) o Scopus, el resto fueron evaluadas y categorizadas según el índice h5. A continuación, en la figura 3 se presentan los límites del h5 correspondientes al periodo comprendido entre el 1 de enero de 2012 y el 31 de diciembre de 2016 y con el cual se asignaron las categorías del área en la Convocatoria N. ${ }^{\circ} 768$.

Figura 3. Límites del h5 (2012-2016) correspondientes a la Convocatoria $\mathrm{N}$ $^{\circ} 768$ para el área de ingeniería y tecnología.

\begin{tabular}{|l|l|l|l|l|}
\hline Maximo & Limite 01-02 & Limite 02-03 & Limite 03-04 & Minimo \\
\hline 14.0 & 6.0 & 3.0 & 3.0 & 2.0 \\
\hline
\end{tabular}

Fuente: resultados finales Convocatoria N. ${ }^{\circ} 768$ de 2016, etapa II, clasificación oficial [6].

Desde el año 2016, el Equipo Editorial de RUI, el Comité Editorial y el Comité Científico, con el apoyo del Consejo de la Facultad de Ingenierías Fisicomecánicas, la Vicerrectoría de Investigación y la División de Publicaciones de la Universidad Industrial de Santander, formularon e implementaron estrategias de mejoramiento con el objetivo de aumentar la visibilidad y el impacto de las publicaciones de la revista. Inicialmente, se incrementó la cantidad de artículos publicados y la frecuencia de publicación, esto se consiguió a partir de la estandarización del proceso editorial y de la optimización del flujo de trabajo de RUI. También se implementó el servicio Early View para mejorar los indicadores de inmediatez, en el cual se publican los artículos después de la recepción de las pruebas corregidas de los autores, siendo estos completamente citables. Otras de las estrategias desarrolladas fueron el fortalecimiento de la interacción en sistemas bibliográficos de indexación y resumen (Latíndex, Redalyc, Ebsco, Dialnet, Emerging Sources Citation Index, Redib, Doaj, Miar, PKP Index, etc.), la participación en redes sociales, un proyecto de extensión dirigido al desarrollo de charlas sobre elaboración de producción científica en las universidades del área metropolitana de Bucaramanga y corrección de estilo de los documentos en español e inglés. 
También se elaboraron estudios y análisis de citación y de redes bibliométricas a las publicaciones realizadas por la Revista UIS Ingenierías. A partir de estos estudios, se observaron las características específicas propias de los artículos publicados, la dinámica, los patrones de interacción y la evolución en la revista. Para ello se utilizaron diferentes softwares libres como VOSviewer, visualizing scientific landscape [7], Ucinet [8] y Publish or Perish (PoP) [4]. Estos estudios permiten orientar al Comité Editorial y al Comité Científico en la toma de decisiones, evaluación y proyección de los objetivos de la revista.

En el año 2018 se dio apertura a la Convocatoria N. ${ }^{\circ} 830$ para la Indexación de Revistas Científicas Colombianas Especializadas Publindex, la segunda bajo el modelo, y en esta ocasión la categoría lograda tendrá vigencia por un año, es decir, hasta el 2020. Según la Resolución N. ${ }^{\circ} 1094$ de 2019, con resultados finales de la Convocatoria N. ${ }^{\circ} 830$ de 2018 [9], publicada el 8 de agosto de 2019, se registraron en total 573 revistas, de la cuales 275 cumplieron con los requisitos para ser categorizadas.

En esta oportunidad se presentaron 69 revistas en el área de ingeniería y tecnología, de las cuales 32 fueron clasificadas, el $49 \%$ de las revistas del área quedó sin categoría. De las 32 revistas categorizadas, ninguna se ubicó en la categoría A1 ni A2, 19 se ubicaron en la categoría B y 13 en la categoría C (ver figura 4).

Figura 4. Distribución del ecosistema de revistas del área de ingeniería y tecnología, Convocatoria N. ${ }^{\circ} 830$ de 2018.

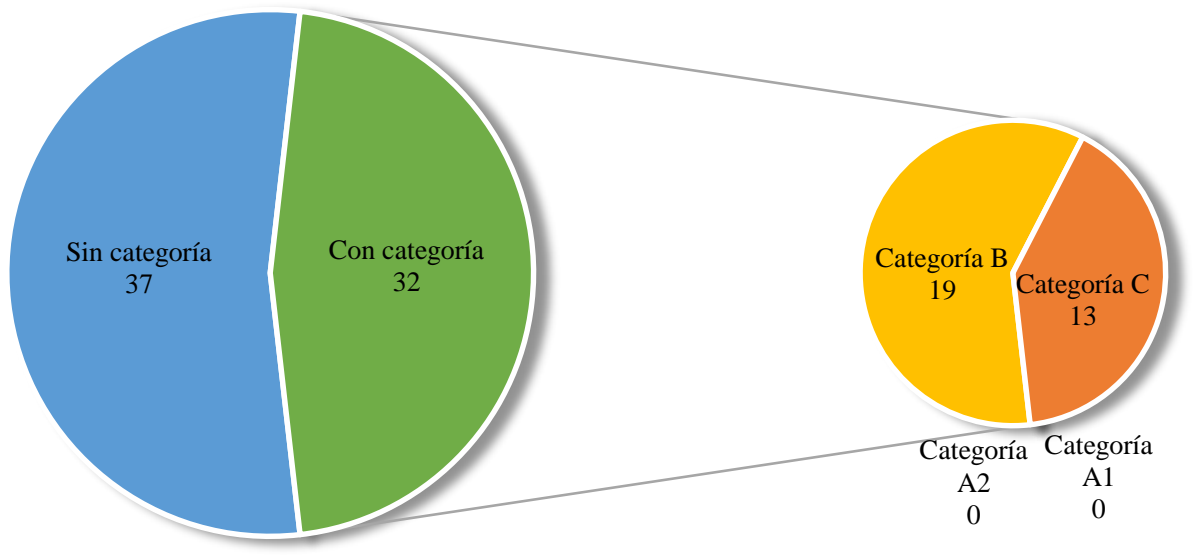

Fuente: elaboración propia.

De las 69 revistas del área de ingeniería y tecnología, 5 continúan indexadas en Web of Science (WoS) o Scopus, el resto fueron evaluadas y categorizadas según el índice h5. A continuación, en la figura 5 se presentan los límites del h5 correspondientes al periodo comprendido entre el 1 de enero de 2013 y el 31 de diciembre de 2017 y con el cual se asignaron las categorías del área en la Convocatoria N. ${ }^{\circ} 830$ de 2018.

Figura 5. Límites del h5 (2013-2017) correspondientes a la Convocatoria N. ${ }^{\circ} 830$ para el área de ingeniería y tecnología

\begin{tabular}{|l|l|}
\hline Valores de los limites & Cuartil del H5 \\
\hline $17-9$ & Q 1 \\
\hline $8-6$ & Q 2 \\
\hline $5-4$ & Q 3 \\
\hline $3-2$ & Q 4 \\
\hline
\end{tabular}

Fuente: resultados finales Convocatoria N. ${ }^{\circ} 830$ de 2018 [10]. 
El esfuerzo y la dedicación por parte de todos los colaboradores de RUI se vio reflejado en los resultados de la convocatoria, la Revista UIS Ingenierías ascendió de la clasificación C con h5 (2012-2016) de 5 a la clasificación B con un h5 (2013-2017) de 12; cabe destacar que esta es la categoría más alta posible para una revista que no está indexada en Scopus o WoS.

Finalmente, el Equipo Editorial de la Revista UIS Ingenierías se complace en publicar el cuarto número del volumen 18, correspondiente a octubre-diciembre de 2019. Se agradece a todos los autores y a los evaluadores por sus contribuciones, y a los lectores, por su interés.

\section{Referencias}

[1] Colciencias, Modelo De Clasificación De Revistas Científicas-Publindex Dirección De Fomento a La Investigación. Colombia, 2016.

[2] "Políticas editoriales," Revista UIS Ingenierías, 2019.

[3] J. E. Hirsch, “An index to quantify an individual's scientific research output," Proc. Natl. Acad. Sci., vol. 102, no. 46, pp. 16569-16572, Nov. 2005.doi: 10.1073/pnas.0507655102

[4] "Publish or Perish,” 2019. [Online]. Available: https://harzing.com/resources/publish-or-perish.

[5] Dirección de Fomento a la Investigación, “Informe de la Convocatoria para Indexación de Revistas Científicas Colombianas Especializadas - Publindex," Colciencias, 2017. [Online]. Available: http://www.colciencias.gov.co/sites/default/files/informe-resultados-publindex.pdf.

[6] Colciencias, "Resultados finales Convocatoria No. 768 de 2016 - etapa II 'clasificación oficial,"” Publindex, 2016. [Online]. Available: https://scienti.colciencias.gov.co/publindex/. [Accessed: 24-Sep-2019].

[7] "VOSviewer-visualizing scientific landscape," 2019. [Online]. Available: https://www.vosviewer.com/.

[8] “UCINET,” 2019. [Online]. Available: https://sites.google.com/site/ucinetsoftware/home.

[9] Colciencias, Resolución n. ${ }^{\circ} 1094$ de 2019, resultados finales convocatoria 830 de 2018. Colombia, 2019.

[10] Colciencias, "Resultados finales Convocatoria No. 830 de 2018," 2019. [Online]. Available: https://scienti.colciencias.gov.co/publindex/ReporteMedicion/resultados.do?src=PUB\&cod_revista=35\&cod_corrida $=20$.

Ivonne Sáenz Suárez

Coordinadora editorial

Universidad Industrial de Santander

\section{Alberto David Pertuz Comas} Editor

Universidad Industrial de Santander

\section{Luisa Fernanda Uribe Forero}

Auxiliar editorial

Universidad Industrial de Santander 


\section{Novelties in the ecosystem of Colombian journals in the area of engineering and technology}

The aim of this editorial is to put in context the current situation of the Colombian Journals in the area of engineering and technology since the application of the new model of classification of scientific journals determined by Publindex [1]. Also, to mention the category promotion of the Revista UIS Ingenierías from category C to category B in Publindex, and to describe the impact of some activities done to achieve the promotion.

In Colombia, scientific journals are classified by Colciencias, which at the same time has the Servicio Nacional de Indexación de Publicaciones Especializadas Seriadas de Ciencia, Tecnología e Innovación - "Publindex", responsible for evaluating the quality of the articles published in the country.

Revista UIS Ingenierías (RUI), is a peer-review publication, releasing four editions per year, edited by the Faculty of Physicomechanical Engineering at Universidad Industrial de Santander. Since 2002, this journal has been the space of dissemination of research developed by academics and professionals of engineering, industrial design and applied sciences contributing to the share of scientific knowledge between individuals and national and international entities driven by similar purposes [2].

Between 2016 and 2017, a new model of classification of scientific journals was implemented [1], through which Colciencias adopted evaluation tools in line with international trends, such as, impact indicators and the incorporation in the Sistemas de Indexación y Resumen, all of this with the purpose of adjusting the scientific and editorial quality standards in Colombia and increasing the impact of the scientific national publications. According to the changes and finding itself in a non-favorable position, RUI started an adaptation process to fulfill the criteria of Publindex.

The new model of classification of scientific journals, groups the publications based on the categorization of the Organización para la Cooperación y el Desarrollo Económicos (OCDE), in six clusters of areas of knowledge, these are: Agricultural Sciences, Medical and Health Sciences, Engineering and Technology, Natural Sciences, Social Sciences and Humanities. Revista UIS Ingenierías is categorized in the area of Engineering and Technology.

Figure 1 shows the relationship between the evaluation process and the criteria set out in the model of classification of scientific journals. It is shown that the classification is determined by the impact indicator, where the indexed journals in bibliographic databases, such as Web of Science (WoS) and Scopus, receive the category following the assigned quartile within the databases, Journal Citation Reports (JCR) and Scimago Journal \& Country Rank (SJR) respectively. For journals not indexed in these databases, the indicator corresponds to the $\mathrm{h} 5$ index [3], calculated using the free software Publish or Perish (PoP) [4].

Figure 1. Evaluation process and the criteria set out in the model of classification of scientific journals

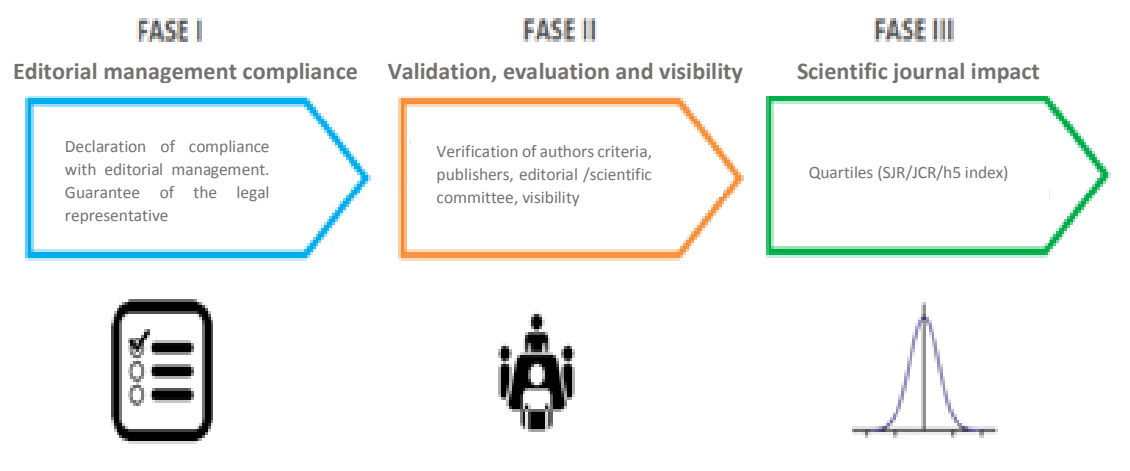

\begin{tabular}{|r|c|c|}
\hline Category & $\begin{array}{c}\text { JCR } \\
\text { o } \\
\text { SJR }\end{array}$ & $\begin{array}{c}\text { h5 } \\
\text { (measured } \\
\text { with PoP, } \\
\text { minimum 2) }\end{array}$ \\
\hline A1 & Q1 & n/a \\
\hline A2 & Q2 & n/a \\
\hline B & Q3 & Q1 \\
\hline C & Q4 & Q2 \\
\hline \multicolumn{2}{|c|}{ without category } & Q3 \\
\hline \multicolumn{2}{|c|}{ without category } & Q4 \\
\hline
\end{tabular}

Source: Own elaboration according to [1].

ISSN impreso: 1657 - 4583. ISSN en línea: 2145 - 8456, CC BY-ND 4.0 (c) (i) @

I. Sáenz-Suárez, L. F. Uribe-Forero, A. Pertuz-Comas, "Novedades en el ecosistema de revistas colombianas del área de ingeniería y tecnología," Rev. UIS Ing., vol. 18, no. 4, pp. 7-14, 2019. doi: 10.18273/revuin.v18n4-2019018 
In 2016, the call $\mathrm{n} .{ }^{\circ} 768$ "for the indexing of specialized scientific Colombian journals" was opened by Publindex. This was the first under the new model and the category obtained was valid for two years, 2018 and 2019 . According to the report of the call n. 768 [5], published in September of 2017 by the Dirección de Fomento a la Investigación, there were registered a total of 627 journals, of which 244 were categorized.

In the area of Engineering and Technology, 76 journals applied and only 30 were classified, $61 \%$ of the journals in this area were left out of categories. From the 30 categorized journals, none receive the classification A1, one was classified in the category A2, 10 in category B and 19 in category C (Figure 2). Revista UIS Ingenierías (RUI) achieved category C.

Figure 2. Distribution of the ecosystem of journals in the area of Engineering and Technology, call n. ${ }^{\circ} 768$ of 2016.

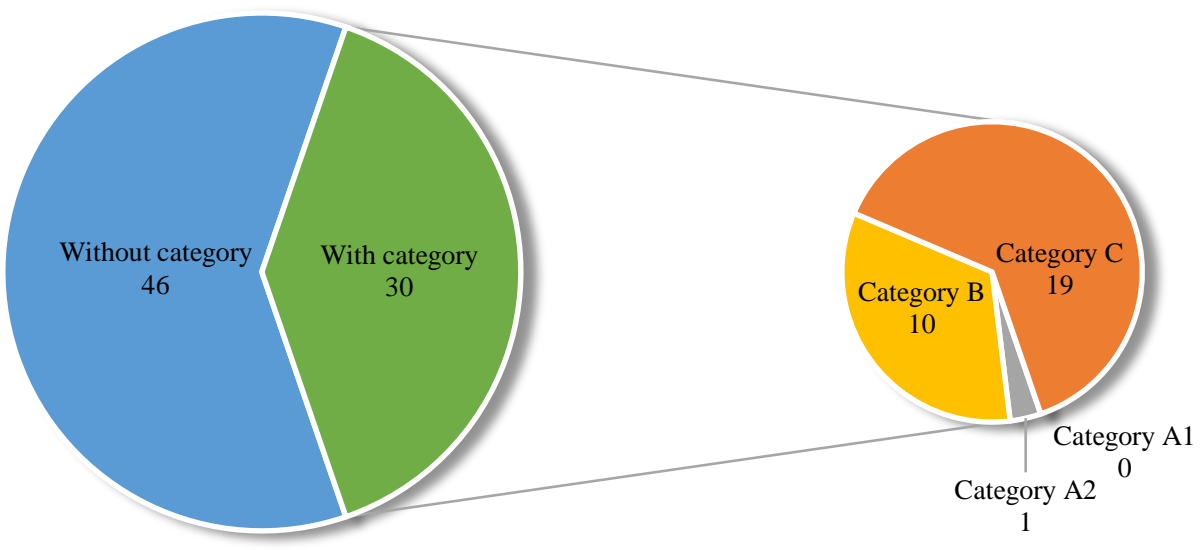

Source: Own elaboration.

From the 76 journals in the area of Engineering and Technology, 5 were indexed in Web of Science (WoS) and/or Scopus, the rest were evaluated and categorized according to the h5 index. Figure 3 shows the limits of the h5 corresponding to the period between January 1st, 2012 to December $31^{\text {st }}, 2016$ used to assign the categories in the area in the call n. ${ }^{\circ} 768$.

Figure 3. Limits of the h5 (2012-2016) corresponding to the call n. ${ }^{\circ} 768$ for the area of Engineering and Technology

\begin{tabular}{|l|l|l|l|l|}
\hline Max & Limit Q1-02 & Limit 02-03 & Limit 03-04 & \multicolumn{1}{|c|}{ Min } \\
\hline 14.0 & 6.0 & 3.0 & 3.0 & 2.0 \\
\hline
\end{tabular}

Source: Final results of the call n. ${ }^{\circ} 768$ of 2016 - Stage II "Clasificación oficial"[6].

From 2016, the editorial board of RUI, the editorial and the scientific committees, with support of the council of the Faculty of Physicomechanical engineering, vice-chancellor of research and the publishing division of Universidad Industrial de Santander, implemented strategies of improvement with the objective of raising the visibility and the impact of the publications of the journal. Initially, the number of published articles and the frequency of issues were increased, this was achieved by standardizing the editorial process and the optimization of the workflow of RUI. Also, the Early View service (articles are published after the reception of the corrected proofs of the authors, these are immediately citable) was implemented. Other strategies were the strengthening of the interaction in bibliographic databases of indexation and resume (Latíndex, Redalyc, Ebsco, Dialnet, Emerging Sources Citation Index, Redib, Doaj, Miar, PKP Index, etc), social media participation, conferences regarding the preparation of articles in universities from the metropolitan area of Bucaramanga, and correction of style in Spanish and English of the documents.

We also performed studies and analysis of citations and bibliometric networks of the publications from Revista UIS Ingenierías. Based on these, the specific characteristics of the published articles, the dynamic, interaction patterns and the evolution of the journal were observed. For that, free software such as VOSviewer-visualizing scientific 
landscape[7], Ucinet [8] and Publish or Perish (PoP) [4] were used. These studies oriented the editorial and scientific committees in the decision making, evaluation, and projection of the objectives of the journal.

In 2018 the call n. ${ }^{\circ} 830$ "for the indexing of specialized scientific Colombian journals" was opened by Publindex, the second under the model. This time, the category achieved was valid for one-year term, during 2020. According to the resolution . $^{\circ} 1094$ of 2019 - final results of the call 830 of 2018 [9], published the 8th of August of 2019, 573 journals applied, of which 275 fulfilled the requirements to be categorized.

In this opportunity, there were 69 journals in the area of Engineering and Technology, of which 32 were classified, $49 \%$ of the journals were left out of the category. None of the 32 classified journals were categorized in A1/A2, 19 were in category B and 13 in category C (Figure 4).

Figure 4. Distribution of the ecosystem of journals in the area of Engineering and Technology, call n. ${ }^{\circ} 830$ of 2018

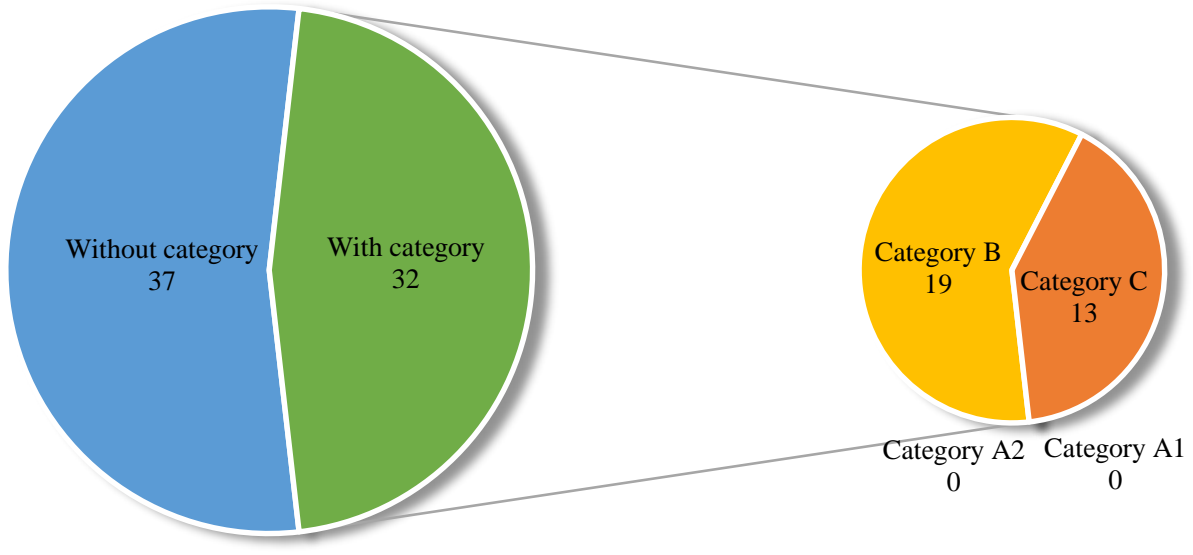

Source: Own elaboration.

From the 69 journals in the area of Engineering and Technology, 5 continued to be indexed in Web of Science (WoS) and/or Scopus, the rest were evaluated and categorized according to the h5 index. Figure 5 presents the limits of the h5 used to assign the categories of the area in the call n. ${ }^{\circ} 830$ of 2018 , corresponding to the period between January 1st, 2013 and the December 31 ${ }^{\text {st }}, 2017$.

Figure 5. Limits of h5 (2013-2017) corresponding to the call n. ${ }^{\circ} 830$ for the area of Engineering and Technology

\begin{tabular}{|l|l|}
\hline \multicolumn{1}{|c|}{ Limit values } & \multicolumn{1}{c|}{ H5 } \\
\hline $17-9$ & Q 1 \\
\hline $8-6$ & Q 2 \\
\hline $5-4$ & Q 3 \\
\hline $3-2$ & Q 4 \\
\hline
\end{tabular}

Source: Final Results of the call No. 830 of 2018[10].

The effort and dedication by all the RUI members was shown, the Revista UIS Ingenierías moved from category C with h5 (2012-2016) of 5, to category B with h5 (2013-2017) of 12. It is worth mentioning that this is the highest possible category for a journal that is not indexed in Scopus and/or WoS.

Finally, the editorial team of the Revista UIS Ingenierías is pleased to publish the fourth issue of volume 18, corresponding to October - December of 2019. All the authors and reviewers are thanked for their contributions, and the readers for their interest. 


\section{References}

[1] Colciencias, "Modelo De Clasificación De Revistas Científicas - Publindex,” 2016.

[2] Revista UIS Ingenierías, "Políticas editoriales," Universidad Industrial de Santander, 2019. [En línea]. Disponible en: https://revistas.uis.edu.co/index.php/revistauisingenierias/about

[3] J. E. Hirsch, “An index to quantify an individual's scientific research output," Proc. Natl. Acad. Sci., vol. 102, no. 46, pp. 16569-16572, Nov. 2005. doi: 10.1073/pnas.0507655102

[4] "Publish or Perish,” 2019. [Online]. Available: https://harzing.com/resources/publish-or-perish.

[5] Dirección de Fomento a la Investigación, "Informe de la Convocatoria para Indexación de Revistas Científicas

Colombianas Especializadas - Publindex," Colciencias, 2017. [En línea]. Disponible en: http://www.colciencias.gov.co/sites/default/files/informe-resultados-publindex.pdf.

[6] Colciencias, "Resultados finales Convocatoria No. 768 de 2016 - Etapa II 'Clasificación oficial,” Publindex, 2016. [En línea]. Disponible en: https://scienti.colciencias.gov.co/publindex/. [Accessed: 24-Sep-2019].

[7] "VOSviewer-visualizing scientific landscape," 2019. [Online]. Available: https://www.vosviewer.com/.

[8] "UCINET," 2019. [Online]. Available: https://sites.google.com/site/ucinetsoftware/home.

[9] Colciencias Convocatoria 830 De 2018 Para La Indexación De Revistas Científicas. Resolución No. $1094,2019$.

[10] Colciencias, "Resultados finales Convocatoria No. 830 de 2018," 2019. [En línea]. Disponible en: https://scienti.colciencias.gov.co/publindex/ReporteMedicion/resultados.do?src=PUB\&cod_revista=35\&cod_corrida $=20$.

Ivonne Sáenz Suárez

Coordinadora editorial

Universidad Industrial de Santander

\section{Luisa Fernanda Uribe Forero}

Auxiliar editorial

Universidad Industrial de Santander

\section{Alberto David Pertuz Comas Editor \\ Universidad Industrial de Santander}

